\title{
School Principal's Time Management as per the Experience of Vice-principals of Primary Schools stage in Najran City
}

\author{
Dr : Salman Refan ALsharif \\ doctor : education administration, Ministry of education, Kingdom of Saudi Arabia, Najran city
}

\begin{abstract}
The study aimed to identify to what extent the principles at the primary stage care about time management from the experience of vice-principals in Najran region. The population of the study consisted of 59 vice-principals in the primary stage in Najran region. Nine questionnaires were excluded as they were not fully completed, and thus 50 questionnaires were valid. The study was carried in the academic year 1438-1439 H.

The researcher applied the descriptive method. The sample of the study composed of 46 items distributed to three domains: the most important aspects of time management by the principals at the primary stage, the most important violations of time management by th

e principals at the primary stage, identifying the most important methods of time management by the principals at the primary stage from the experience of vice-principals and teachers. The questionnaire's validity and reliability were verified.

The results of the study showed that the overall average of the aspects of the principals' time management in the primary stage was medium with a means of 3.21 and standard deviation .730 . The results also revealed that the average of the violations of time management by the principals at the primary stage was medium and scored a means of 3.15 and standard deviation of .667. In addition, the results also reported that the most applied method at the schools is the self-management method with a means of 3.30, followed by the goal-based management (3.18). The method of acting management came last (3.07).
\end{abstract}

Keywords: Time Management, Schools stage in Najran City

DOI: $10.7176 / \mathrm{JEP} / 10-3-09$

\section{Introduction}

The progress and promotion of nations and peoples can only be achieved by proper managing of their time in a wise and sincere manner. Therefore, management has not been seen as an automatic process that does not require development, training and good preparation, but it has become seen as an educational and administrative leadership that presiding school. It has moral managerial and administrative duties through which the educational system runs within the school in a manner that satisfies all needs of all employees. The school principal must be aware of the course of work assigned to him, manages it wisely, allocates time to important tasks, determines their start and end, and ensures their success.

Ahmed (1991) noted that "Successful school management is the cornerstone of education and the educational process. It sets out milestones and outlines ways, and enlightens the staff in the field of education by reviewing tasks and following up the results in a meaningful way. This helps to review regulations, amend and assess methods of implementation through which the desired objectives can be achieved, in this sense, time is one of the most vital resources of the school administration through which the desired goals is achieved with a degree quality and perfection, and as the institutions of the entire society are interested in time management. However, in this area school administration is an important component of the educational system. Time for the school principal is an important element in plans and programs preparation, along with the consequent actions and activities that need continuous follow-up. Success is achieved taking into account the natural, social and cultural environment. The principal represents the important element in the educational system. He is supposed to have the ability to achieve the goals of the educational institution as he utilizes most of his time in achieving those goals as there are heavy burdens entrusted to him. He has to organize and divide his time during the school day. Accordingly, the importance of managing the time of primary school principals in Najran is highlighted in this study.

\subsection{Literature Review:}

Time is important in all fields of life and it is one of the most precious and rare resources in the life of human beings. Our true religion emphasizes time importance in the holy Quran and the Sunnah of the Prophet (Peace be upon him) according to their cultural, intellectual and religious theories and as Aliyan (2005) pointed out; there are fundamental differences in how the importance of time between societies is seen. The developed societies have a great interest in time and how to distribute it. This concern and attention is less in developing societies.

Islam stressed the importance of time through the Prophet's Hadith (Peace be upon him") which stated that: "Take five before five: your youth before your aging, your health before your sickness, your richness before your poverty, your leisure before your busyness and your live before your death". However, developed countries were 
concerned with the management of time and how to exploit and take advantage of it, depending on the changes of times, as it affects the whole life details, from thinking through planning down to production.

The management of time in the educational process and activities is very important for the success of the entire institution as it is agreed by researchers and others that each task carried out by individuals, institution and the population aims to achieving these results. Therefore, each person exerts his own effort, energy, thinking and potential to achieve what he wants with the least possible effort and cost. In this regard, we consider here the educational process. Al-Ghaithi $(1422 \mathrm{H})$ noted that: "The importance of time management is illustrated by the method by which managers manage the time. It determines their identity in terms of the values they believe in, attitudes towards work, understanding of time and their attitudes towards it, which is decisive for effectiveness in their departments in terms of influencing employees and their relationships."

Al-Khodrari (2000) said that the importance of time management "is evident through the sound and effective management of human resources and staff, so that it gives a progressive dimension to work and employees, in addition to satisfaction, enjoyment and efficiency to reach the greatest achievements."

Mansour (1993) noted that the organization of time management "has become important in the official work as it represents one of the effective inputs in pushing the processes of administrative development and advancement, and the success of institutions in achieving their goals efficiently and effectively."

Hence, the researcher believes that time management is important for every person and we have succeeded here in the successful management through the planning, organization, implementation and follow-up, through the personality traits and knowledge of the administrative field that has a positive impact on the workers and the entire educational process. "Setting priorities and objectives is the key to any effort, and the main focus of the planning process. Time management is possible, and by time management, achieving goals becomes possible."

We refer here to the successful Manager, through planning, organization, implementation and follow-up, through the character traits and knowledge of the administrative field, which has a positive impact on the workers and the entire educational process; Abu Sheikha (1991) stated that setting priorities and objectives is the key to any effort and the main focus of the planning process. Through time management goals can become achievable.

It is necessary to organize the time for each action and process implemented by the school principal or his staff so that the educational system can go well, that this time is enough for each task, Al-Abbudi (1423 H) defined time by saying, "The time is required to carry out tasks and to acquire, possess and manage the means we need to implement a designed plan."

Administrative methods are also considered important aspect of time management as they define the relationship between teachers and the school administration, as well as between the school administration and its visitors, through the principal attitude and his educational methods, his scientific qualification and being openminded which qualifies him to assume the responsibilities entrusted to him. The methods that can be followed by the school principal in his administration are: Management method of goals. Where Sherif (2003) stressed that: management by objectives contributes to the development of a number of competencies for the success of the school principal through setting priorities and using the information and data available to him in making decisions in organizing his work and practices it in a smooth manner, and the successful manager is able to convince teachers and administrators so as to motivate them to work and raise their capabilities in order to achieve the desired goals.

As far as the management method of delegation is concerned, he shows that good time management is directly related to the good delegation of tasks and the work of other people. It is also an effective regulatory means to empower subordinates within a specific framework. This leads to cooperation among them. Regarding Self-Management, Al-Ghaithi $(1422 \mathrm{H})$ stated that it is a method that requires administrative leadership of high degree of self, managerial, technical and behavioral skills and is capable of adapting to the continuous changes, new forms and patterns of organizations that emerged as a result of rapid technological development.

The school administration is an important educational field worthy of further study, attention and development. This development contributes to increasing the effectiveness of the school administration and the whole system in its educational field.

Al-Fayez (1992) defined the school administration as ""A group of organized efforts carried out by individuals within a single framework in order to achieve the educational goals that are designed and reflected in the impact on society."

Al Naji (1426) and Al-Aghbar (2000) explained that there are some administrative functions that are successful in achieving the educational system, including: strengthening the relationship between the school administration, administrators, teachers and students, and motivating teachers, which increases the spirit of competition and achievement among them.

There are several studies that dealt with time management each in its own, and there is a link between these studies which all focused on time management, and they were varied according to their titles, including: Al Zahrani Study (2005- 1426 H). The title of the study is "Time Management in Frontier Guards in Makkah Al- 
Mukramah area". "The purpose of this study was to identify the effective use of time management methods and also to identify the obstacles that limit its effectiveness". The sample of the study was a group of Frontier Guard's officers in the Makkah Al-Mukramah area. The results of the study indicate that a large majority of the study sample agree on all the proposed solutions to rationalize time management in the Frontier Guards in Makkah Al-Mukramah. There are also negative roles for the technical, technological, personal and organizational obstacles of the officers in terms of optimal utilization of time. The purpose of this study was to identify the effective use of time management methods, as well as the obstacles that limit its effectiveness. The sample of the study was a group of Frontier Guards' officers in Makkah Al-Mukramah area. The results of the study indicated that the majority of the study sample agrees on all the proposed solutions to rationalize time management in the Frontier Guards in Makkah Al-Mukramah area. There are also negative roles for the technical, technological, personal and organizational obstacles of the officers regarding optimal utilization of time.

Al-Rashid Study (2003-1424 H) Title of the study "Time Management and its Relation to Work Pressures", an applied study on the heads of departments and divisions, in the Frontier Guards in Dammam and Riyadh. The researcher's study aimed to finding out the relation of time management to the work pressures of the department heads and supervisor of the Frontier Guards departments in the cities of Dammam and Riyadh. The study sample consisted of a group of department managers and heads of the Frontier Guards in the said. The results of the study found that there is a strong but negative correlation between work pressure and time management variables, the more prudent and good management that respects the time the less the pressures of work.

Al-Shami study $(2002,1423)$, entitled "The most Prominent Methods that hinder the Utilization of Official Time allocated to the educational Process - Field Study in Schools of General Education for Girls."

This study aimed at the most important methods that hinder the investment of official time allocated to the educational process in the general education schools for girls in Makkah. The results of this study revealed the disappearance of the variable of experience for the sample of the study in determining the degree of 19 reasons that hinder the investment of the official time allocated to the process While there were 14 reasons for the lessexperienced category, and the disappearance of the variable of the function occupied by the sample of the study in determining 18 degrees of the reasons that hinder the investment of the official time allocated to the educational process, the effect of this effect in determining 15 causes. There are also reasons in the questionnaire to impede the investment of time in educational science for girls in the teaching of Mecca the most important of which is stopping teaching before the official date during the holidays of Eid al-Fitr and Adha due to the absence of students in these two seasons.

Al-Ghamdi Study $(2000,1421 \mathrm{H})$, titled "Time Management for General Secondary School Students in Jeddah and Al-Mahawiya" The study aimed to finding out how secondary students benefit from time management and what are the methods used. A sample of secondary school students in Al-Mahwah and Jeddah. The results of the study showed the prevalence of the phenomenon of delay and night at night, which led to not to wake up early, especially on weekends, and the total spending of students to sleep seven hours and twenty minutes, while students devote time in basic social activities, whatever the field of three hours The total of what the study population spends on prayer, worship, and other religious matters is one hour and six minutes per day. The total of what is spent in studying and solving the duties is seven hours and five minutes. It is divided as follows: One hour and fifty minutes of duties and study, five hours and a quarter, While M. Students devote to time in social and cultural activities free of entertainment, entertainment, or whatever the space of eight hours per day. The results of the study also showed that there is no statistically significant difference between the students of the two governorates through the practice of social activities, worship, sleep and other social activities, as well as organizing time for the study, and a third of the study society set up a time plan but did not abide by it The results of the study showed that there are statistically significant differences between the students in these governorates in terms of sleep time, wake up and social activities, there are hours for the students of Jeddah to practice social activities while Al-Mahwah province allocated a number of hours to sleep and wake up.

Al-Ghamdi study (1990), this study aimed to finding out how time management among primary school principals during the working hours. The results of the study showed that the percentage of time spent by the principal during the school day was the administrative share with $31.81 \%$ Followed by the follow-up of extracurricular activities (6.36\%), parents' interview (6.97\%) followed by the percentage of students $(15.45 \%)$ and teachers $(20 \%)$.

Biddy's Study-(1995) entitled "Time Management for Managers and Directors of Government Secondary Schools in Amman Governorate", unpublished Master Thesis, Yarmouk University, Faculty of Educational Sciences. The aim of the study was to know the time management of the director and principals of the public secondary schools in Amman. The study also aimed to explaining the effect of the variable between the two sexes in terms of managerial experience and qualification in how to manage official time during the working hours. The study also aimed to revealing the nature of activities and tasks Including the director and secondary managers. The sample of the study was composed of the director and directors of public secondary schools in the 
city of Amman. The results of the study showed that the respondents in the sample of the study responded to the questionnaires in three items, where their responses in the humanitarian field were medium, in the technical and administrative fields high, and there were statistically significant differences at level 5. Among the responses of the secondary school principals and managers, and there were no statistically significant differences at the level of 5. Between the response averages of the secondary school principals and the managers in how time management is attributed to the administrative experience and the scientific qualification.

Atkins (1990), "The Relationship between the Use of Time Management Techniques and Functional Stress Sources in Secondary Schools in the United States of America". The aim of this study is to demonstrate the use of time management technology, and to determine the relationship between the use of time management techniques by the school principal and sources of functional stress. The study sample consisted of secondary school principals in the United States of America. The results of the study showed that most of the sources of functional stress faced by the manager are related to the workload and time problems. The study also showed that managers do not use time management in an appropriate and useful manner.

\subsection{Statement of the problem:}

There is no doubt that the success of school principal in accomplishing the responsibilities entrusted to him is due to his abilities, skills and good planning of his time by benefiting from the courses and educational programs in time management. The researcher was briefed on a number of researches and studies which dealt with time management. Among these studies were Sulaiman (1413H), Al-Ghamdi (1410H), Atkins (1410H), Al-Thubaiti $(1407 \mathrm{H})$ and Al-Obeidi and Almani' (1402H). Also, there is a study by researcher Alzahrani (1426H) on time management and organization within the targeted group of school principals. All of these studies, which address the time management of school principals, are subject to a lot of waste and lack of training programs and incentives provided to them, which may be a waste of time extended to the public or private sectors, both civilian and military personnel. Principals of the primary stage in the city of Najran are the targeted group in this study, which drew the attention of the researcher to this matter. Hence, the problem can be framed in the main question: What is the extent of the interest of the principals of the primary stage in time management from the experience of Vice-principals' in Najran city?

This question is divided into the following questions:

1. What are the most important aspects of time management among primary school principals from the experience of Vice-principals?

2. What are the most important practices that interfere with the time management of primary school principals from the experience of Vice-principals?

3. What are the most important time management methods for primary school principals from the experience of Vice-principals?

\subsection{Study Objectives}

This study aims at identifying the following:

To know the most important aspects of time management among primary school principals from the experience of Vice-principals.

To identify the most important practices that interfere principals' time management of schools from the experience of Vice-principals.

To identify the most important methods of time management for primary schools principals from the experience of Vice-principals.

\subsection{Importance of the Study:}

Studies in their various branches emphasized the importance of time management and that was covered by Mustafa (2005) and Al-Aghbar (2000), where Mustafa stated that time management is "one of the five capabilities that provide school principal with administrative efficiency which can be acquired and developed for the principal by acquirement or development". Whereas, Al-Aghbar said that time management for a school principal is not a matter of minutes or hours, but rather specific results and goals that should be accomplished within the specified time ".

Hence, we say that the importance of the study stems from this aspect as it addresses an important matter in the field of education in various types of roles, responsibilities and tasks, in order to contribute to school's success in the educational process through the following points:

1. The most prominent practices that compromise time management among primary school administrators.

2. The most prominent administrative methods followed by primary stage principals in time management.

3. The reality of time management of the primary stage principals from the experience of Vice-principals of Najran City.

4. Time management planning for primary school administrators. 
5. The importance of this study derives from the importance of this stage.

\subsection{Limits of the Study}

1. Objective Limits: Knowledge of time management among the principals of primary stage in Najran City from the experience of the Vice-principals.

2. Spatial Boundaries: Primary schools in Najran city.

3. Time Limits: The study was applied in the first semester of the academic year 1438/1439 H (2017 2018 $\mathrm{AD})$.

\subsection{Study Terminologies}

1. Time Management: The researcher believes that the management of time in this study is a comprehensive administrative process through the tasks and activities carried out by school principals so as to produce an integrated educational system.

2. Time Management Aspects: The researcher believes that the aspects of time management are what the principal of the school performs during the school day; beginning with planning to the end of implementation in the shortest time in the least possible effort and the educational goals achieved as monitored by school Vice-principals.

3. Time Management Methods: The researcher believes that methods of time management are the methods and the best ways which benefit school principal in terms of scientific qualification, relationship with his fellow Vice-principals and teachers, and personal convictions.

4. Practices that interfere with Time Management: The researcher believes that the practices that interfere with time management are some of the tasks and activities carried out by the school principal without having a positive return on the educational process.

\section{Methodology:}

\subsection{Population and sample}

The study population consists of the primary education Vice-principals in the city of Najran, south of Saudi Arabia. The number of primary schools within the city of Najran (78) is distributed on the outskirts of the city. Of these, 19 schools have no Vice-principals; The researcher distributed the questionnaires to all the school Vice-principals. The number of questionnaires returned was (55) questionnaires and the missing (4), (55) (5) were excluded because they were not valid for different reasons and the number of valid questionnaires was (50). This was in the semester: 1438/1439 H.

\subsection{Study Tool:}

After reviewing the educational literature and previous studies related to the current study, a questionnaire was constructed in the final form of (46) sections distributed on (3) axes: Measuring the level of time management aspects of primary school principals from the experience of Vice-principals, namely (16), Measured the level of time management practices of primary school principals from the experience of Vice-principals, namely (16) words, measuring the degree of the practice of time management methods of principals of primary schools from the experience of Vice-principals, the three (14) phrases.

\subsection{The truest internal consistency of the study tool:}

The researcher used the correlation coefficient (Pearson) to measure the correlation between each paragraph and each axis, from the axes of the study instrument, indicating that the internal validity of the study instrument was achieved. The researcher investigated this by finding Pearson coefficients between each term and the total score.

\subsection{Validity the study tool:}

The validity of the study instrument was measured by:

Virtual honesty of the study tool:

To validate the content of the study tool, it was presented to a group of arbitrators in the field of management, and educational planning of the members of the teaching staff and educational supervisors in the field of school management and a group of principals of the primary stage, and asked them to express a visual concern about the appropriateness and comprehensiveness of the paragraph content of the axis, and the level of the language of the paragraph, and any comments they see, in terms of modification, Where the observations were taken and suggestions and made the appropriate amendments through their recommendations, and the researcher considered that these amendments by the arbitrators is the apparent honesty of the study tool. Table 1 . 
Table 1. Internal Consistency of the Study Instrument and its axes

\begin{tabular}{|c|l|c|}
\hline SR & Internal Consistency of the Study Instrument & Correlation Factor \\
\hline 1 & Time management aspects & $822^{* *}$ \\
\hline 2 & Time management practices & $768^{* *}$ \\
\hline 3 & Time management methods & $728^{* *}$ \\
\hline
\end{tabular}

Table .1 shows a statistically significant correlation at the level of (0.01) among the axes of the study instrument and the instrument as a whole, which confirms that the study instrument paragraphs are interrelated and verify the validity of internal consistency.

\subsection{Stability of the study instrument}

Stability was calculated using "Kronbach Alfa" method by applying the study tool to the sample of the study (46). The table (2) shows the values of the stability coefficients of the study tool axes and the tool as a whole.

Table 2. Stability coefficients of the study instrument and its axes

\begin{tabular}{|c|l|c|c|}
\hline SR & $\begin{array}{l}\text { Stability of the study instrument and its } \\
\text { axes }\end{array}$ & No. of Samples & $\begin{array}{l}\text { Stability as per "Kronbach } \\
\text { Alfa" method }\end{array}$ \\
\hline 1 & Time management aspects & 16 & 0.89 \\
\hline 2 & Time Management - wasting Practices & 16 & 0.87 \\
\hline 3 & Time management methods & 14 & 0.88 \\
\hline & Total & 46 & 0.94 \\
\hline
\end{tabular}

Statistical Processing: The Statistical Analysis Program (SPSS) was used. The statistical averages and standard deviations were used to answer the first question to find out the level of time management, the level of time management practices and the degree of time management practices in primary school principals in Najran. Vice-principals. The degree of practice is determined by the classification of the arithmetical averages according to the scale $(4.20-5)$, very large $(3.40-4.20),(2.60-3.40), 1.80-2.60$ (low), $1.80-1.80$.

Table 3. The Arithmetic Average and the Percentage of the Instrument of the Study tool

\begin{tabular}{|c|c|c|c|}
\hline SR & Average from & To less than & Practice \\
\hline 1 & 4.20 & 5 & Very large degree \\
\hline 2 & 3.20 & 4.20 & Great degree \\
\hline 3 & 2.60 & 3.40 & Average degree \\
\hline 4 & 1.80 & 2.6 & Low grade \\
\hline 5 & 1 & 1.80 & Very low grade \\
\hline
\end{tabular}

\section{Results}

4.1Results of the first question: What are the most important aspects of time management among elementary school principals from the experience of Vice-principals?

To answer this question, the arithmetic mean, standard deviation and percentage weight of all the terms of this question were extracted to ascertain the degree of actual practice of these contents, whose results include Table 4. and the following graphic presentation:

Table 4. Arithmetical averages, standard deviations and percentage weight of the time management aspects of primary school administrators.

\begin{tabular}{|c|l|c|c|c|c|}
\hline SR & phrase average scale & $\begin{array}{l}\text { Arithmetic } \\
\text { Mean }\end{array}$ & $\begin{array}{l}\text { standard } \\
\text { deviation }\end{array}$ & $\begin{array}{l}\text { Centric } \\
\text { weight }\end{array}$ & $\begin{array}{l}\text { Application } \\
\text { Degree }\end{array}$ \\
\hline 1 & Early planning of its tasks & 3.06 & 1.490 & 61.2 & Average \\
\hline 2 & Existence of a schedule for his daily work & 2.96 & 1.340 & 59.2 & Average \\
\hline 3 & $\begin{array}{l}\text { Distribution of responsibilities among } \\
\text { employees in an effective manner }\end{array}$ & 2.78 & 1.502 & 55.6 & Average \\
\hline 4 & $\begin{array}{l}\text { Distribution of responsibilities to } \\
\text { employees from the beginning of the year }\end{array}$ & 3.54 & 1.487 & 70.8 & Large \\
\hline 5 & $\begin{array}{l}\text { To seek to develop his professional } \\
\text { performance by all available means }\end{array}$ & 3.04 & 1.511 & 60.8 & Average \\
\hline 6 & $\begin{array}{l}\text { Evaluates his work continuously } \\
\text { for school work }\end{array}$ & 3.11 & 1.374 & 62.2 & Average \\
\hline 8 & $\begin{array}{l}\text { Organizes work from the most important } \\
\text { to the important }\end{array}$ & 3.10 & 1.359 & 62 & Large \\
\hline 9 & $\begin{array}{l}\text { Accuracy in all appointments and } \\
\text { compliance }\end{array}$ & 3.68 & 1.077 & 73.6 & Average \\
\hline 10 & $\begin{array}{l}\text { Respond to formal transactions on time } \\
\text { Provides a general plan full of elements }\end{array}$ \\
\hline
\end{tabular}




\begin{tabular}{|c|l|c|c|c|c|}
\hline SR & phrase average scale & $\begin{array}{l}\text { Arithmetic } \\
\text { Mean }\end{array}$ & $\begin{array}{l}\text { standard } \\
\text { deviation }\end{array}$ & $\begin{array}{l}\text { Centric } \\
\text { weight }\end{array}$ & $\begin{array}{l}\text { Application } \\
\text { Degree }\end{array}$ \\
\hline 11 & $\begin{array}{l}\text { Follow up on the completion of the } \\
\text { administrators on a continuous basis }\end{array}$ & 3.24 & 1.572 & 64.8 & Average \\
\hline 12 & $\begin{array}{l}\text { Distribute time on all activities needed by } \\
\text { work }\end{array}$ & 2.68 & 2.68 & 53.6 & Average \\
\hline 13 & $\begin{array}{l}\text { Officials' sudden visits do not affect his } \\
\text { daily schedule }\end{array}$ & 2.94 & 2.94 & 58.8 & Average \\
\hline 14 & $\begin{array}{l}\text { Balancing business requirements and } \\
\text { special circumstances }\end{array}$ & 3.16 & 1.419 & 63.2 & Average \\
\hline 15 & $\begin{array}{l}\text { Use different means of communication in } \\
\text { a way that helps him to accomplish his } \\
\text { work }\end{array}$ & 3.50 & 1.359 & 70 & Large \\
\hline 16 & $\begin{array}{l}\text { To be an example to his colleagues in } \\
\text { attendance and departure }\end{array}$ & 3.10 & 1.388 & 62 & Average \\
\hline General average & 3.21 & .730 & .730 & Average \\
\hline
\end{tabular}

Table 4. shows that the general average of the time management principals in of the primary stage reached (3.21), with a standard deviation (0.730) with middle degree. This is due to the lack of principals' responsibility for the time and its role in improving the school administration, and the highest manifestations of time, paragraph (10), "Response to formal transactions on time", with an average of (3.90) and a standard deviation (0.974) And to a large extent attributed the reason for this because the appearance of routine features that require immediate action as well as may attribute the reason so there are no penalties or responsibilities delay the response to official transactions, and came in the second paragraph (9) "accuracy in all dates and commitment to" with an average of 3.68 and a standard deviation of 1.077. This is mainly due to the principals taking routine action as a profession ethics and emphasizing its importance. The third paragraph (7) provides a general plan, School "with an arithmetic mean (3. 56) and standard deviation (1.327). This is also due to the nature of the emphasis on the routine procedures of the management work, including the preparation of plans and schedules and circulation to the teachers.

While paragraph (3) "Utilizes his time in school effectively" with an average of 2.78 and a standard deviation of 1.502 and an average degree. The reason is the implementation and activation of written plans into practical procedures that may be attributed to lack of training in time management courses. Paragraph (12), distribution of time attained all the activities needed by the work, with an arithmetic average (2.68), standard deviation (1.362) and an average degree. This is due to poor implementation of written plans into practical froms and procedures.

4.2 Results of the second question: What are the most important practices that interfere with the time management of primary school principals from the experience of Vice-principals?

To answer this question, the arithmetic mean, standard deviation and percentage weight of all the terms of this question were extracted to ascertain the degree of actual practice of these contents, whose results include Table 5. and the following graphic presentation:

Table 5. Arithmetical averages, standard deviations and percentage weight which violates time management practices of primary school administrators.

\begin{tabular}{|c|c|c|c|c|c|}
\hline SR & Phrase Average Scale & $\begin{array}{l}\text { Arithmetic } \\
\text { Mean }\end{array}$ & $\begin{array}{l}\text { Standard } \\
\text { Deviation }\end{array}$ & $\begin{array}{l}\text { Centric } \\
\text { Weight }\end{array}$ & $\begin{array}{c}\text { Application } \\
\text { Degree }\end{array}$ \\
\hline 1 & $\begin{array}{l}\text { Does not schedule daily work as specified in } \\
\text { his plan }\end{array}$ & 3.72 & 1.400 & 74.8 & Average \\
\hline 2 & Holding sudden and unplanned meetings & 3.26 & 1.759 & 65.2 & Average \\
\hline 3 & Weak ability to organize work & 3.04 & 1.665 & 60.8 & Average \\
\hline 4 & $\begin{array}{l}\text { Weakness of ability to deal with emergency } \\
\text { conditions }\end{array}$ & 3.30 & 1.359 & 66 & Large \\
\hline 5 & Hesitation in making decisions & 3.64 & 1.425 & 72.8 & Average \\
\hline 6 & $\begin{array}{l}\text { Its dependence on a specific administrative } \\
\text { method }\end{array}$ & 3.24 & 1.437 & 64.8 & Average \\
\hline 7 & $\begin{array}{l}\text { Weak ability to build trust relationships with } \\
\text { employees }\end{array}$ & 2.62 & 1.354 & 52.4 & Large \\
\hline 8 & $\begin{array}{l}\begin{array}{l}\text { Weakness of keeping pace } \\
\text { developments in his field }\end{array} \\
\text { dith new }\end{array}$ & 2.74 & 1.337 & 54.8 & Average \\
\hline 9 & $\begin{array}{l}\text { Poor knowledge of the characteristics of the } \\
\text { stage that he is managing }\end{array}$ & 3.38 & 1.469 & 67.6 & Large \\
\hline
\end{tabular}




\begin{tabular}{|l|l|l|l|l|l|}
\hline SR & Phrase Average Scale & $\begin{array}{l}\text { Arithmetic } \\
\text { Mean }\end{array}$ & $\begin{array}{l}\text { Standard } \\
\text { Deviation }\end{array}$ & $\begin{array}{l}\text { Centric } \\
\text { Weight }\end{array}$ & $\begin{array}{c}\text { Application } \\
\text { Degree }\end{array}$ \\
\hline 10 & Frequent and Unplanned Visits by Fellows & 2.64 & 1.425 & 52.8 & Large \\
\hline 11 & $\begin{array}{l}\text { Identification of tasks delegated to vice- } \\
\text { principals and employees }\end{array}$ & 3.56 & 1.280 & 71.2 & Average \\
\hline 12 & $\begin{array}{l}\text { Attention to administrative work without the } \\
\text { technical aspect }\end{array}$ & 3.38 & 1.123 & 67.6 & Average \\
\hline 13 & $\begin{array}{l}\text { Poor qualification and character traits to } \\
\text { manage the stage }\end{array}$ & 3.28 & 1.400 & 65.6 & Average \\
\hline 14 & $\begin{array}{l}\text { Engaging in his own activities and frequent } \\
\text { departures }\end{array}$ & 2.94 & 1.316 & 58.8 & Average \\
\hline 15 & Frequent use of phone calls & 2.78 & 1.569 & 55.6 & Large \\
\hline 16 & Weak communication system and levels & 2.88 & 1.547 & 57.6 & Average \\
\hline General average & 3.15 & .667 & 63 & Average \\
\hline
\end{tabular}

Table 5. shows that the general average of the time management interfering practices in primary school principals is 3.15 , with a standard deviation (0.667) and the average degree. Paragraph (1) "did not schedule the daily work as specified in his plan" (3.72) and by a standard deviation (1.400) and to a large extent due to awareness of school principals of the most important manifestations of disruption in time management, the second was the practice of "hesitation in decision making" with an average of 3.64 and an average of 1.425. This was due to the fact that school principals had theoretical aspects or theoretical knowledge of practices that interfere with time management. The weak ability to build trust relationships with employees was at the lowest mean (2.62) and with a standard deviation (1.354) and to a average degree. Paragraph (10) "frequent and unplanned colleagues' visits" ranked before the last position with an average of 2.64 and a standard deviation (1.425) and average degree.

Most of the important interfering of time management among primary school principals is represented in an average degree, with the exception of paragraphs (1), (5) and (11), according to primary school Vice-principals, which showed that the most important practices that interfere with time management are not daily scheduled work, hesitation in making decisions and determining of the tasks assigned to Vice-principals and employees. This is due to the possession of some theoretical aspects of the most important practices that interfere with the management of time and since the axis includes many of the important paragraphs including practices that interfere with the management of time, but it got a middle degree and the researcher believes that the reason is due to poor perception by managers Schools are influenced by time management practices. Since the axis includes many paragraphs that are important in that they include practices impeding the management of time, but it got an average degree and the researcher believes that the reason for this is due to poor perception by school principals of the impact of time management practices.

4.3 Results of the third question What are the most important methods of time management of primary school principals from the experience of Vice-principals?

To answer this question, the arithmetic mean, standard deviation and percentage weight of all the terms of this question were extracted to ascertain the degree of actual practice of time management methods:

First: Management by Objectives

Table 6. Arithmetical averages, standard deviations and percentage weight of management method to objectives from the time management methods of primary school principals.

\begin{tabular}{|l|l|c|c|c|c|}
\hline SR & Phrase Average Scale & $\begin{array}{l}\text { Arithmetic } \\
\text { Mean }\end{array}$ & $\begin{array}{l}\text { Standard } \\
\text { Deviation }\end{array}$ & $\begin{array}{c}\text { Centric } \\
\text { Weight }\end{array}$ & $\begin{array}{c}\text { Application } \\
\text { Degree }\end{array}$ \\
\hline 1 & $\begin{array}{l}\text { Exploiting all material and technical } \\
\text { resources to achieve the objectives }\end{array}$ & 3.24 & 1.333 & 64.8 & Average \\
\hline 2 & $\begin{array}{l}\text { Utilizing the time available to } \\
\text { effectively accomplish all business }\end{array}$ & 2.94 & 1.316 & 58.8 & Average \\
\hline 3 & $\begin{array}{l}\text { Balancing the setting of objectives and } \\
\text { the efforts of workers and available } \\
\text { time }\end{array}$ & 2.92 & 1.563 & 58.4 & Average \\
\hline 4 & $\begin{array}{l}\text { Identifying some business objectives } \\
\text { with colleagues }\end{array}$ & 3.44 & 1.417 & 68.8 & Large \\
\hline 5 & $\begin{array}{l}\text { Setting a time frame for achieving } \\
\text { business objectives }\end{array}$ & 3.38 & 1.441 & 67.6 & Average \\
\hline General average & 3.18 & 1.020 & 63.6 & Average \\
\hline
\end{tabular}

Table 6. shows that the management method by objectives showed an average of (3.18), a standard 
deviation (1.020) with an average degree. Paragraph (4) "Determination of some of the objectives of the work with his colleagues" was obtained at the highest mean of the average (3.44), a standard deviation of (1.447) and to an average degree ad paragraph (5) obtained "Determination of time frame to achieve the work objectives, on average degree (3.38), standard deviation (1,441, and with large degree. Paragraph (3) "The balance between setting goals and efforts of workers and available time" attained at least Arithmetic averages with an arithmetic mean (2.92) and standard deviation of (1.563), with an average degree. The reason for determining some objectives of the work with colleagues and setting a time frame for achieving the objectives of the work is at the highest averages. This may be due to the following-up of school principals and vice-principals to routine procedures in the management method in school administration. Researcher attributed the reason that most of the paragraphs of the axis of the management method by objectives on the average degrees may be due to lack of awareness and understanding of principals and Vice-principals of primary schools to the management by objective method by objectives as a method of time management and lack of coordination between the objectives and efforts of the worker, perhaps the reason is due to the lack of understanding of vice-principals schools abilities of teachers who supervise them and their ability to achieve.

Second: The Method of Management by Delegation

Table 7. Arithmetical averages, standard deviations and percentage weight of management method by delegation from the time management methods of primary school administrators.

\begin{tabular}{|l|l|c|c|c|c|}
\hline SR & Phrase Average Scale & $\begin{array}{c}\text { Arithmetic } \\
\text { Mean }\end{array}$ & $\begin{array}{c}\text { Standard } \\
\text { Deviation }\end{array}$ & $\begin{array}{c}\text { Centric } \\
\text { Weight }\end{array}$ & $\begin{array}{c}\text { Application } \\
\text { Degree }\end{array}$ \\
\hline 1 & $\begin{array}{l}\text { Identifying tasks delegated to vice- } \\
\text { principals and employees }\end{array}$ & 2.78 & 1.329 & 55.6 & Average \\
\hline 2 & $\begin{array}{l}\text { Providing the opportunity to develop } \\
\text { staff performance and abilities }\end{array}$ & 2.96 & 1.551 & 59.2 & Average \\
\hline 3 & $\begin{array}{l}\text { Assigning the tasks to the workers } \\
\text { according to their qualifications and } \\
\text { abilities }\end{array}$ & 2.98 & 1.505 & 59.6 & Average \\
\hline 4 & $\begin{array}{l}\text { Bearing responsibility with his } \\
\text { colleagues to who he delegated some of } \\
\text { his powers }\end{array}$ & 3.58 & 1.247 & 71.6 & Average \\
\hline
\end{tabular}

Table 7. shows that the management method by delegation of the principals at the primary level was calculated with an average of 3.07 and a standard deviation of 1.160 and an average degree. Paragraph (4) "Bears responsibility with his colleagues who delegated some of his powers". Paragraph (3) "assigning tasks to employees according to their qualifications and abilities" ranked second (2.96) and a standard deviation (1. 551). the reason for this is attributed to school principals being less awareness of the less of management by delegation, but they are more accountable to the people who delegated them. This confirms principals' respect and moral commitment. If others are delegated to them. This confirms the principals' respect and moral commitment if others are delegated to them. They do not evade the consequences of decisions taken if others are delegated.

Third: Self- management Method

Table 8.Arithmetical averages, standard deviations and percentage weight of the Self-management method in particular for the time management for primary school administrators.

\begin{tabular}{|c|c|c|c|c|c|}
\hline SR & Phrase Average Scale & $\begin{array}{c}\text { Arithmetic } \\
\text { Mean }\end{array}$ & $\begin{array}{c}\text { Standard } \\
\text { Deviation }\end{array}$ & $\begin{array}{c}\text { Centric } \\
\text { Weight }\end{array}$ & $\begin{array}{c}\text { Application } \\
\text { Degree }\end{array}$ \\
\hline 1 & $\begin{array}{c}\text { The attention to development in order to } \\
\text { improve the performance }\end{array}$ & 3.46 & 1.092 & 69.2 & Large \\
\hline 2 & $\begin{array}{c}\text { Employing human and material resources to } \\
\text { achieve the best results }\end{array}$ & 3.24 & 1.408 & 64.8 & Average \\
\hline 3 & $\begin{array}{c}\text { Flexibility and understanding of emergency } \\
\text { situations }\end{array}$ & 2.86 & 1.578 & 57.2 & Average \\
\hline 4 & $\begin{array}{c}\text { Relying on his skills and abilities in } \\
\text { accomplishing the work }\end{array}$ & 3.48 & 1.249 & 69.6 & Large \\
\hline 5 & $\begin{array}{c}\text { Determine the time to accomplish the most } \\
\text { important work }\end{array}$ & 3.48 & 1.282 & 69.6 & Large \\
\hline & General Average & 3.30 & .767 & 66 & Average \\
\hline
\end{tabular}

Table 8. shows that the management method of the principals at the primary level was of average degree with a mean (3.30) and a standard deviation (0.767). Paragraph (4) and (5) "Skills and ability to complete the work", ""Determining the time to accomplish the most important work" obtained the highest averages (3.48) and (1.249) respectively, while (3) "Flexibility and understanding of emergency conditions" obtained at the lowest 
averages (2.86) and by standard deviation (1.578) with an average degree, This is due to the low level of employment, the human, technical and material resources available in schools to improve the level of performance and the desire for individuality in power, inefficiency and participation by others.

Table 9. Arithmetical averages, standard deviations and percentage weight of time management methods among primary school administrators

\begin{tabular}{|c|c|c|c|c|c|}
\hline SR & Phrase Average Scale & $\begin{array}{l}\text { Arithmetic } \\
\text { Mean }\end{array}$ & $\begin{array}{l}\text { Standard } \\
\text { Deviation }\end{array}$ & $\begin{array}{c}\text { Centric } \\
\text { Weight }\end{array}$ & $\begin{array}{c}\text { Application } \\
\text { Degree }\end{array}$ \\
\hline 1 & Self-management method & 3.30 & .767 & 66 & Average \\
\hline 2 & Management method by objective & 3.18 & 1.020 & 63.6 & Average \\
\hline 3 & Management method of delegation & 3.07 & 1.160 & 61.4 & Average \\
\hline \multicolumn{2}{|c|}{ General Average } & 3.20 & 0.905 & 64 & Average \\
\hline
\end{tabular}

Table 9. shows that the most methods applied by the school principals are the self-management method (3.30) followed by the management method with the goals (3.18) and the last rank is the management method with an average of (3.07). The reason is that the self-management method is at the highest level of the principals' desire to take control of everything.

\section{Discussion}

1. The researcher believes that the response of the members of the study population was of a average degree. This may be due to the weakness and lack of awareness of the principals of the primary stage of the importance of time and its role and importance in improving the educational process, which may be due to the weakness and lack of training courses for school principals in terms of time management.

2. The researcher believes that the response of the members of the study population was of a average degree. This may be due to the poor understanding of the principals of the primary stage of the practices that interfere with the management of official time during work and may be due to the lack of sufficient knowledge in terms of theoretical and practical frameworks in time management and practices of impeding time.

3. The researcher believes that the response of the members of the study population was of an average degree, perhaps due to poor understanding of the principals of the primary stage of this matter, lack of principals understanding of management by objectives and lack of awareness of theoretical frameworks and practical skills of management by objectives method, The researcher believes that the response of the members of the study population was of an average degree may be due to the lack of confidence of managers to assign their work to others, do not assign tasks logically and follow-up on a continuous basis. The lack of awareness of the principals of the primary stage of this matter, and the lack of knowledge of principals in the management of the objectives and the lack of practical frameworks skills of this method, This is due to the low level of self-management among principals in primary schools and the hesitation to make decisions, especially in the emergency situations of those decisions, which may be reflected in thinking and the consequent responsibility that affects the career,

\section{Conclusion}

1. Conducting training courses for school principals on an ongoing basis on time management and practices and modern management techniques in time management.

2. Demonstrating successful experiences of the most organized and time-consuming managers.

3. Provision of specialized courses in the manifestations and methods of time management by experts in this field. In order to train them in how to set goals and time for each goal clearly, reflecting positively in the distribution of responsibilities on the process of education in the right framework according to the time set for them.

4. Provision of the opportunity for the principals of the primary stage to develop themselves, through fulltime courses of not less than six months or a full year and be full-time in the field of management, for development and renewal.

5. Conducting a similar study on primary school principals in the provinces and regions of the Kingdom of Saudi Arabia to compare these studies.

\section{References}

Abu Sheikha, Nader Ahmed (1991) Time Management, Dar Majdalawi Publishing and Distribution, Jordan.

Ahmed, Ibrahim Ahmed (1991) Towards the Development of School Management Theory and Field Studies, I 2, Alexandria, New Publications House.

Al-Ghamdi, Moeed Saeed (1410H) Time Management for Principals of Primary Schools in Jeddah, Unpublished Master Thesis, Umm Al-Qura University, College of Education, Makkah Al-Mukramah.

Time Management of Industrial Secondary School Directors in Dakahlia Governorate, (1993). Future Conference of Technical Education in Egypt, Association of Modern Education, in cooperation with the Faculty of Education, Ain Shams University, Cairo. 
Al-Aghbar, Abdul Samad (2000) School Management, the Contemporary Planning and Regulatory Dimension, i. Beirut, the Arab Renaissance House.

An analytical study of the daily work of primary school's principals, middle and secondary schools in Saudi Arabia, (1982). Journal of the Faculty of Education, King Saud University, Riyadh.

Mustafa, Laheb Abdel Hamid (2005) 1425 school administration in the light of contemporary administrative thought, Dar al-Marikh, Riyadh.

Alian, Rabhi Mustafa (2005), Time Management and Theory, Dar Jarir Publishing and Distribution, Amman.

Salama, Suhail Fahd (1988) Time Management A Progressive Method to Success, Arab Organization for Administrative Sciences, Jordan.

Al-Ghaithi, Fahd Muhammad (1421H) Methods of Time Management and Educational Practice from my point of view The directors of the security departments, unpublished master thesis, Umm Al-Qura University, Faculty of Education, Makkah Al-Mukramah.

Khodrari, Mushin Ahmed (2000 AD) Cultural Time Management, Atirak Publishing and Distribution, Cairo.

Mansour, Farouk Helmi (1993) 1403, Weekly Leave and Time Management in Administrative Units, Journal of Management, Issue 2, Cairo.

Sherif, Abdin Mohamed (2003) The Role of Management in Objectives in Developing the Administrative and Professional Efficiency of the School Director, Educational Magazine, Issue 66, Volume XVII.

Al Naji, Muhammad Abdullah (2005). Educational and school administration, theories and practices, Madinah Press, Saudi Arabia.

Al-Aghbar, Abdul Samad (2000) School Management, Dar Al-Nahda Al Arabiya, Beirut, Lebanon.

Ghamdi, Amira Rashid (1990), the Ideal, Formal and Realistic Role of the High School Principal, Comparative Study in Jeddah, Unpublished Master Thesis, King Saud University, Riyadh.

Shami, Haifa Hassan (2002) The most prominent methods that hinder the investment of official time allocated to the educational process field study in schools of general education for girls, unpublished master thesis, Umm Al-Qura University, Faculty of Education, Makkah Al-Mukramah .

Al-Shamrani, Muhammad Jaber (1421) Time Management of the Student Guide in Higher Education Schools in the Holy Capital, unpublished Master Thesis. Umm Al-Qura University, Faculty of Education, Makkah AlMukramah.

Al-Qarni, Ali Said (1417H) Time Management: A Field Study on the Exploitation of the Saudi Director of Time in Government Bodies in Riyadh, Unpublished Master Thesis, King Saud University, Riyadh.

Ishaq Muhammad (1420 H) Time Conservation Method, I 2, Al-Humaidhi Printing Press, Riyadh.

Asaad, Walid Ahmed (2005) School Management, Arab Society Library for Publishing and Distribution, Amman

Al-Busi, Abdullah Mubarak (2005) Time Management Art, Taiba House for Publishing and Distribution, Riyadh

Badis, Hala Hassan (1995) Time Management for Managers and Directors of Government Secondary Schools in Amman Governorate, Unpublished Master Thesis, Yarmouk University, Faculty of Educational Sciences.

Al-Jabr, Zaynab Ali (1998) Time Management of the Directors of the School Management Development (Field Study) College of Education, Educational Magazine, Issue 47, Journal 12, Kuwait University, Kuwait.

Al-Humaidhi, Abdullah M. (1415H) Time Management for Umm Al-Qura University Students, Umm Al-Qura University, Educational and Psychological Research Center.

Al-Khuzama, Abdul Hakam Ahmad (db) Time Management = Life Management, Contemporary Management Series, Ibn Sina Library for Publishing and Distribution, Cairo.

Al-Dawwani, Kamal $(1408 \mathrm{H})$ A study of the reality of the administrative behavior of principals and principals of secondary schools in Jordan, Al Mustansiriya Magazine, no. 16.

Al-Zuheibi, Sahl Ali (1419H) Managing the teacher's time in a variety of roles and duties, unpublished master's thesis, Umm Al-Qura University, Makkah Al-Mukramah .

Al-Rashed, Jehad Muhammad (1424H) Time Management and its Relation to Work Stress: An Empirical Study of Department Directors and Heads of Departments at the Border Guards in Riyadh and Dammam, Unpublished Master Thesis, Naif Academy for Security Sciences, Department of Administrative Sciences.

Al-Sufayani, Ayedh Abd Al-Muti $(1421 \mathrm{H})$ Time Management, Training Unit, Teaching the Holy Capital, Makkah Al-Mukramah.

Al-Sufayani, Ayedah Abdul-Mu'ti (1422H). Features of Time Management in the Holy Quran and its Applications in Educational Administration, Unpublished Master Thesis, Umm Al-Qura University, Makkah Al-Mukramah.

Taha, Nahla Abdelkader (1996) Development of the school administration in basic education in the Arab Republic of Egypt in light of the concept of time management, abstract unpublished doctoral thesis, Ain Shams University, Faculty of Education.

Abdel-Jawad, Mohamed Ahmed (20001420) How to manage your time effectively, training and selfdevelopment series, Dar al-Bashir for Culture and Science, Tanta. 
Asfour, M. Shaker (1400) How to occupy the manager for the official working hours, applied study at the level of middle administration in the Kingdom of Saudi Arabia, Institute of Public Administration, Riyadh.

Al-Fayez, Abdullah Abdul Rahman (1992, 1413) Educational Administration and School Management, Safir Press, Riyadh.

Mutawa, Jassim Mohammed (1990, 1410) Time Ammar or destruction, Dar Al Dawa for publication and distribution, Kuwait.

Heinz, Marion $(2001,1421)$ Time Management, Administrative Development Series, Translation Abdullah Bilal, Dar Al Maarafa Human Development, Riyadh.

Abu Adwa, Fawzi Harb (1998) The reality of administrative and technical practices for secondary school principals in the Gaza district, unpublished master thesis, Faculty of Education, Al-Azhar University, Gaza.

Ahmed, Ibrahim Ahmed (1991) Towards the Development of School Management Theory and Field Studies, I 2 , Alexandria, New Publications House.

Al-Badri, Tariq Abdel-Hamid (2001) Leadership and administrative methods in educational institutions, 1, Amman, Dar al-Fikr for printing.

Al-Ghamdi, M. Radeef (1421H) Time Management for Students in the General Secondary School in Jeddah and Al-Mahawiya, Unpublished Master Thesis, Umm Al-Qura University, College of Education, Makkah AlMukramah.

(1995) entitled "Time Management for Managers and Directors of Government Secondary Schools in Amman Governorate", unpublished Master Thesis, Yarmouk University, Faculty of Educational Sciences. 